\title{
Strategy of Developing Local Economy Based on Regional Superior Commodities
}

\author{
Arie Eko Cahyono ${ }^{1} \&$ Lioni Indrayani ${ }^{2}$ \\ ${ }^{1}$ Institute Teacher Training and Education, PGRI Jember, Jawa Timur, Indonesia \\ ${ }^{2}$ Economic and Business Faculty, Universitas Pamulang, Banten, Indonesia \\ Correspondence: Lioni Indrayani, Economic and Business Faculty, Universitas Pamulang, Banten, Indonesia. Tel: \\ 628-111-312-306. E-mail: dosen02626@unpam.ac.id
}

Received: April 30, 2020

Accepted: May 29, 2020

Online Published: June 5, 2020

doi:10.5539/ijef.v12n7p11

URL: https://doi.org/10.5539/ijef.v12n7p11

\begin{abstract}
This paper discusses the strategy of developing a local economy based on regional superior commodities. There are not many peoples can process the superior commodities to be derivative products that have added value. Also, the limited access to price information and marketing networks forces farmers to sell their crops to collectors at a price that is determined unilaterally, that is why farmers do not get the maximum benefit. The purpose of this study is to formulate a leading commodity-based on local economic development strategy to create competitiveness to improve the people's economy. This study uses descriptive analyses with a quantitative approach and is supported by location quotient (LQ), shift-share, and value added analyses. To formulate a strategy, we used a SWOT analysis to determine the program carried out by comparing current conditions to desired conditions and referring to the results of the SWOT analysis. The results of the study show that leading commodities are proven to have comparative advantages and have the potential to become the basis of regional economies. The integrated commodity product processing industry that produces a variety of processed products can provide economic value that increases the final value of superior commodities. Also, the activities of processing derivative products are also able to produce added value, provide profit margins to workers and employers, as well as contribute to other inputs for each kilogram of product produced. Processed products have the potential to provide high price margins to farmers and producers if the marketing system is more efficient. Based on this analysis, industrial clusters based on regional superior commodities can be developed.
\end{abstract}

Keywords: local economic development, superior commodities, people's economy

\section{Introduction}

\subsection{Introduce the Problem}

Since the implementation of regional autonomy in Indonesia, poverty reduction efforts have been carried out in a decentralized manner, by continuously encouraging local governments (provincial, district/city, village) and all other elements of society (universities, business world, non-government organizations/community organizations, and the poor) to participate in poverty alleviation activities that are comprehensive, integrated and sustainable (Duncan, 2007). The enactment of regional autonomy has implications for the region to issue and develop its ability to mobilize and manage the production, allocation, and distribution of its various resources into superior products that have competitive advantages, both for local, regional, national and even international markets. This regional development strategy that is based on local resources is known as the concept of local economic development (Feldman, L., \& Feldman, R., 2014).

This local economic development concept approach provides an opportunity for the community to play a role and initiative in determining and processing local resources, both human and natural resources, to create an economic chain (Raco, 2000). Economic development that is based on local resources like this is expected to be able to absorb labor from local communities and create new jobs that have an impact on improving the local economy, to compete with the surrounding area to reduce regional disparity (Foley, 1992).

A case study in Pronojiwo District, Lumajang Regency, which is the largest salacca zalacca plantation center in East Java. Leading regional commodities based on location quotient (LQ) calculation are salacca zalacca commodities which constitute income and contribute well to the economy in Pronojiwo District. Salacca zalacca 
production in Pronojiwo Subdistrict can be said to be high, in 2017 the production was 25,043,500 kg. However, the abundance of salacca zalacca commodities and the high contribution to the economy in Pronojiwo sub-district is not matched by the welfare of salacca zalacca farmers. This is because farmers are only able to sell zalacca in the form of raw materials, in addition to the lack of information and marketing networks for farmers forcing farmers to sell their harvest to collectors. Also, not many people can process zalacca fruit into a high-value product and produce added value (Cahyono, Kurniawan, Sukidin, \& Kantun, 2018).

Seeing the potential of zalacca commodities that can contribute to the economy, it is necessary to innovate salacca zalacca to be able to create competitiveness and provide added value to the community. So that the potential of salacca zalacca commodities not only benefits the region but can improve the welfare of the community. The innovations created are expected to be carried out sustainably, given that economic competition continues to run and develop.

While this has not been much research discussing the economic role of zalacca commodities, this is important to determine the future of zalacca commodities. Therefore, this study aims to formulate strategies for the development of zalacca-based local economic development to improve the economy and welfare of the community, especially farmers.

\subsection{Theoretical Background and Literature Review}

\subsubsection{Local Economic Development /LED}

Local economic development is a process that involves the formation of new institutions, the development of new industries, the development of the capacity of workers to produce higher quality products, identification of new markets and the establishment of new businesses (Ayandibu \& Houghton, 2017). The role of the regional government in the development of the local economy is very important, in this case the local government has a role in carrying out its function as a pioneer of development, coordinator, facilitator, and stimulator. The role of the regional government is also very important in terms of paying attention to infrastructure used in business and industrial activities, as well as improving the quality of people's lives (Muda et al., 2018).

Local Economic Development is the process by which the public, business and civil society sectors work collectively to create better conditions for economic growth and job creation (Sovacool, Walter, Andrews, \& Graaf, 2016). The aim is to build the economic capacity of a region to improve its economic future and quality of life for all. Successful Local Economic Development must focus on increasing competitiveness, promoting sustainable growth and ensuring that growth is inclusive (Ayandibu \& Houghton, 2017).

The tangible benefits of Local Economic Development, such as employment and infrastructure, enter through local communities to change attitudes, mobilize existing skills, improve networks, think differently about problems and use community assets in new ways. (Nauta, Merola, Caputo \& Evangelista, 2015). Local Economic Development improves the situation of a community not only economically, but as a strong functioning community itself capacity building can create jobs, increase income, and improve infrastructure. Local Economic Development also builds community capacity to fundamentally be better able to manage change (Shi et al., 2016).

\subsubsection{The Concept of Local Commodity-Based Local Economic Development}

Local economic development is a process whereby regional governments and communities manage existing resources by forming partnerships with the private sector to create new jobs and stimulate regional economic activities, to increase the number and various forms of employment available to local communities. In its development, the government and the community are required to put forth ideas for the development to be carried out (Brusca \& Montesinos, 2016).

Agriculture is the largest economic activity for the people of Indonesia, considering that Indonesia is an agricultural country where most of its territory is agricultural land (Nugroho, Pramukanto, \& Negara, 2016). Approximately 55\% of the national workforce is in the agricultural sector and more than $70 \%$ of Indonesia's population depends on the agriculture sector, but the welfare of Indonesian farmers is still relatively low and agricultural output is sometimes a source of inflationary pressure for the region. Therefore it is necessary to carry out agricultural development activities by determining superior commodities so that the handling becomes focused so that it can produce high quantities of products and can compete in the market, both locally and internationally (Maqin \& Sidharta, 2017).

Leading commodities can be viewed from the supply and demand sides. In terms of supply of superior commodities characterized by superiority in its growth in the biophysical conditions, technology and socio-economic conditions of farmers in a region (Gunawan, Cahyono, \& Santoso, 2018). While from the demand side, leading commodities can be seen from the strong demand in both domestic and international markets. 
Determination of superior commodity is the first step towards agricultural development which is based on the concept of efficiency to achieve comparative and competitive advantage in the face of trade globalization. (Kurniawan, Cahyono, Sukidin, \& Kantun, 2019).

Local Economic Development operates with several principles (Pike, Marlow, Mccarthy, \& Brien, 2015):

1) Local Economic Development encourages equitable and sustainable economic growth. Equal opportunities for wealth creation are open for men and women of working age, for the rich and poor, for urban and rural populations, and all ethnic and religious groups. To maintain economic growth, local resources can be transformed into valuable items for the current population but must continue to be regenerated so as not to deprive the same generation of resources in the future.

2) Local Economic Development is a multi-stakeholder partnership. Those who are affected and can influence (for example, governments, businesses, non-governmental organizations and communities) economic growth in the region, have a stake in and play a role in Local Economic Development.

3) The private sector is a recognized engine of work and growth and as such, regional government authorities must be aware of their "enabler" role, that is, setting the right environment for local economic growth. However, local government authorities have carefully decided to provide some services in situations where investors are inadequate or when cartels control commodity prices in the region.

4) Good economics thrives when there is transparent and accountable governance - a practice that must permeate all political and economic structures in society

1.2.3 Local Economic Development Approach

Local economic development approaches include:

a. Competitiveness Development

Competitiveness is not an end goal or a goal, but rather a way to achieve the final goal. The competitiveness of a region is also strongly influenced by the commodity factors that are developed (Malysheva, Shinkevich, Kharisova, \& Nuretdinova, 2016). The selection of commodities in determining competitiveness is crucial, considering the thing that determines competitiveness is commodities.

b. Cluster Development

This strategy provides a framework for local governments to provide services to the entire cluster to provide maximum impact (Seo \& Coo, 2017).

c. Institutional Development

Formal and informal institutions that are formed can complete economic activities based on transactions into a relationship that is based on community beliefs and norms (Pathak \& Muralidharan, 2016).

d. Human Resource Development

In the context of the production process, the existence of good technical mastery will encourage technological innovation. These technological innovations can ultimately create new product discoveries and more efficient ways of production that will simplify the production process (Koji \& Bae, 2015).

e. Technology Mastery

Technology mastery is how the factors of production are combined to realize the goals of production (Ryu, 2019). Using increasingly sophisticated technological capabilities, is expected to create an innovation on a product to provide greater input.

\section{Method}

The method used in the study of Commodity-Based Local Economic Development Strategies is quantitative with a descriptive approach. The analysis conducted in the location of the location quotient (LQ) Quotient, Shift-Share, and SWOT Analysis. The stages of the analysis carried out are:

1) Identification of socio-economic characteristics of salacca zalacca farmers is done by copying the results of the questionnaire data processing into a graph and then describing it according to the results obtained. The identification of farmers' social characteristics is obtained based on age, experience, motivation, and land tenure. While the economic characteristics of farmers are based on the income received at harvest and net income.

2) Identification of the characteristics of zalacca farming activities is carried out to determine the production of 
zalacca, zalacca care, and post-harvest salacca zalacca marketing.

3) Identification of institutional characteristics is carried out to determine the institutions that exist in the community and institutions by the government that supports zalacca farming and development activities to be carried out. Information obtained from questionnaires and field observations. Then the data is processed and presented descriptively.

4) Identification of salacca zalacca derivative products. This identification aims to find out the products that can be produced from salacca zalacca, ranging from trees to fruit. Identification is obtained based on observations and document review which is then presented in the form of derivative images.

5) Value-added analysis is carried out to find out how much-added value is produced from zalacca derivative products so that zalacca commodities are feasible to be developed. Value added analysis results from comparing the price of salacca zalacca raw material with the price of salacca zalacca derivative products that produce the difference in value.

6) Salacca zalacca commodity base sector analysis (a case study of Pronojiwo District). Base sector analysis is carried out to find out the comparative and competitive advantages of zalacca commodities.

7) Formulating local economic development strategies is done by identifying internal and external factors that affect local economic development activities. Then the merger phase is carried out using a SWOT analysis that is compared with the desired conditions in local economic development activities.

\section{Result}

\subsection{Geographical Conditions}

Salacca zalacca Farmers Socio-Economic Characteristics. The age of most zalacca farmers is between 40 - 55 years. Even though this age is classified as productive, the population has the ability to think that it is starting to weaken. This is very influential on the ability of farmers to create innovations on salacca zalacca derivative products. As salacca zalacca farmers in pronojiwo sub-district have a long experience of salacca zalacca farming, which is between 10-20 years. It is proven that until now farmers have not been able to develop salacca zalacca farming more widely. Based on the area of land tenure, the average salacca zalacca farmer has a plantation area with an average area of 1-2 hectares with land ownership status, categorized as land owned and not owned (rent, profit sharing, pawn) (Lund \& Rachman, 2017). The average income received by salacca zalacca farmers in one production period (quarterly) starts from Rp. 2,500,000 - Rp. 5,000,000. The total area of Indonesian zalacca in 2018 reaches 23,204 hectares with a production of 983,000 tons spread across several centers, such as Sleman, Magelang, Banjarnegara, South Tapanuli and Karangasem Regencies (Sukewijaya, Rai, \& Mahendra, 2009). The traditional pattern of salacca zalacca fruit marketing is that farmers sell their produce directly to collectors. By collectors, zalacca are cleaned, sorted, then distributed to order. Although the government has provided a special place to sell salacca zalacca, not many farmers are willing to sell their harvest to the salacca zalacca market. With reason, the price received if selling to the market and collectors is not much different, so selling to collectors is felt easier. Also, farmers do not dare to sell their crops because farmers are afraid that if salacca zalacca is not sold out and rot will reduce income, not to mention the transportation costs incurred to market salacca zalacca. Based on information obtained from salacca zalacca farmers and collectors, Salacca zalacca Pronojiwo District has marketing objectives such as in the surrounding cities such as Malang and Surabaya Regencies.

This market information acts as a key that will help farmers and business actors in determining business strategies, determining the risk borne, determining the selling price and increasing market share. A case study in Pronojiwo Subdistrict, marketing activities are still open, anyone can enter and take the role of the seller. Also, farmers and businesses in the salacca zalacca commodity do not have equal access to market information so that unfair trade is created. Usually the price of salacca zalacca from farmers is very low, when it arrives at the distributor or retailer, the price of salacca zalacca will increase up to 3 times. Local government support in the form of market price information is inadequate, the role of the government in establishing cooperation with other regional governments is still weak.

Salacca zalacca fruit derivative products that have been developed are salacca zalacca porridge, salacca syrup, and zalacca bean coffee. Based on the manufacturer's statement, zalacca coffee coffee has benefits for patients with hypertension, gout, and diarrhea. To make processed products, the raw materials needed do not have difficulties because they are available in their area in abundant quantities.

\subsection{Value Added Value Added Analysis}

Is the difference between the value of production with the value of raw materials other additional materials used to 
produce salacca zalacca derivative products. Value-added analysis is calculated based on raw materials that are processed into products that are ready for sale. Following are the results of the calculation of value-added on salacca zalacca derivative products developed in Pronojiwo District:

Table 1. Salacca zalacca processed products in Pronojiwo District

\begin{tabular}{cllccc}
\hline No & \multicolumn{1}{c}{ Sector } & \multicolumn{1}{c}{ Production result } & Output Sector & Input Sector & Value-added \\
\hline 1 & primary: Agriculture & Salacca zalacca $(\mathrm{kg})$ & 2.500 & 1.800 & 700 \\
\hline 2 & Secondary: Food & Jenang salacca zalacca & 14.000 & 7.500 & 6.500 \\
& industry & salacca zalacca Syrup $(800 \mathrm{ml})$ & 19.000 & 13.000 & 6.000 \\
& salacca zalacca Brownies & 40.000 & 25.000 & 15.000 \\
& & Coffee beans salacca zalacca (100 gr) & 15.000 & 10.000 & 5.0000 \\
& & Chips salacca zalacca (100 gr) & 15.000 & 10.000 & 5.000 \\
\hline
\end{tabular}

Source: research data.

\subsection{Regional Comparative Excellence Analysis Location Quotient (LQ)}

In this study took a case study on salacca zalacca farmers in Lumajang Regency, Pronojiwo District. Food crops classified as leading commodities in Lumajang regency that have or have LQ> 1 as many as 41 commodities, if ranked based on the highest location quotient (LQ) value, zalacca is the most superior commodity (the highest of the others), then papaya, cucumber, watermelon, and banana. This is due to its strategic location, soil type, and land area that are very suitable to be developed. The largest location quotient (LQ) value is the Salacca zalacca commodity with a location quotient (LQ) value of 57.735. Zalacca production shows less consistent development, there has been an increase and decrease. In 2013 salacca zalacca production reached 17,507,600 kg then in 2014 production increased by $18,740,200 \mathrm{~kg}$, in 2015 there was a significant increase of 34,930,400, but in 2016 it decreased to $26,762,500 \mathrm{~kg}$, and in in 2017 it fell again to $24,049,900 \mathrm{~kg}$.

Regional Competitive Advantage Analysis (Shift-Share). Local economic development, in addition to the potential for comparative advantage, it is also necessary to study competitive advantage (Lee, 2016). To find out the changes and shifts in the structure of zalacca commodities or agricultural sub-sectors on a regional or local scale at two-time points, Shift-Share analysis is used. By understanding the activities of zalacca commodities from the results of the Shift-Share analysis, it can also explain the ability of zalacca commodity competition in Pronojiwo District with regional growth. An area is said to have a competitive advantage if in the period time analyzed has experienced a positive shift (increase) for the production of a commodity that can be compared to other regions (Liao, 2014). The results of the Shift-Share analysis of salacca zalacca commodity in Pronojiwo Subdistrict, which was counted against Lumajang Regency as a comparison region in 2014 against 2018, showed that the salacca zalacca commodity in Lumajang Subdistrict contributed to rapid growth over for 5 years (2014 - 2018). This is evidenced by the positive growth value, which is 0.078 . Then competitively, salacca zalacca commodity in Pronojiwo District is also positive, namely 0.727 , which means that the developed commodity has the competitiveness to compete in a wider market share to improve the community's economy.

\subsection{SWOT Analysis}

Swot Analysis of the Result of Local Economic Development Based on Salacca zalacca Leading Commodity in Lumajang District by combining each of the analysis factors. Strategy is the steps taken to achieve the desired conditions in the future based on consideration of current conditions (Park \& Jeong, 2012). In the study of local economic development strategies based on salacca zalacca commodity in pronojiwo sub-district, the strategy is obtained by combining the strengths and weaknesses factors using SWOT analysis with consideration of the conditions to be achieved (Roh, Kim, Yoo, \& Kim, 2015). The strategies obtained are: 


\begin{tabular}{|c|c|c|}
\hline EXTERNAL FACTORS & $\begin{array}{l}\text { OPPORTUNITIES }(\mathbf{O}) \\
\text { 1. Local government support } \\
\text { 2. Regional autonomy policy } \\
\text { 3. Facilities and infrastructure } \\
\text { 4. Technological development } \\
\text { 5. Potential market absorption } \\
\text { 6. Investment and business support }\end{array}$ & \begin{tabular}{|ll} 
THREAT $($ T) \\
1. & Salacca zalacca price instability \\
2. & Little-known trademark \\
3. & Variation of salacca zalacca derivative \\
& products \\
4. & Regional ego \\
5. & Natural disasters \\
\end{tabular} \\
\hline $\begin{array}{l}\text { STRENGTH (S) } \\
\text { 1. Potential natural resources (production, } \\
\text { comparative and competitive advantage) } \\
\text { 2. Home products and home industry alacca } \\
\text { derivative products have added value } \\
\text { 3. Local labor }\end{array}$ & $\begin{array}{l}\text { STRATEGY S-O } \\
\text { 1. Improving the quality and } \\
\text { production of zalacca commodities } \\
\text { 2. Form a LED research institute } \\
\text { 3. Cluster formation. }\end{array}$ & $\begin{array}{l}\text { STRATEGY S-T } \\
\text { 1. Increase the innovation of salacca zalacca } \\
\text { derivative products } \\
\text { 2. Strengthening sales promotion activities and } \\
\text { trademarks } \\
\text { 3. Development of a conducive business climate }\end{array}$ \\
\hline $\begin{array}{l}\text { WEAKNESS (W) } \\
\text { 1. Capital and access to finance } \\
\text { 2. Quality and HR skills } \\
\text { 3. Information and network marketing } \\
\text { 4. Supporting Institutions }\end{array}$ & $\begin{array}{l}\text { STRATEGY W-O } \\
\text { 1. Strengthening the capacity of } \\
\text { supporting institutions } \\
\text { 2. Mobilizing sources of funds for } \\
\text { financing and credit } \\
\text { 3. community development } \\
\text { 4. Form a LED institution }\end{array}$ & $\begin{array}{l}\text { STRATEGY W-T } \\
\text { 1) Build forums and partnerships with other LGs } \\
\text { 2) Technology development }\end{array}$ \\
\hline
\end{tabular}

Figure 1. SWOT analysis

\subsection{Local Commodity-Based Economic Development Strategies}

A strategy is the steps taken to achieve the desired conditions in the future based on consideration of current conditions. In the study of zalacca-based local economic development strategies the strategy is obtained by combining strengths and weaknesses factors using a SWOT analysis with consideration of the conditions to be achieved. The strategy obtained is:

1) Increasing the quality and production of salacca zalacca

In industrial activities, increasing the quality and production of raw materials is very important. This is due to the increasing demand for goods and quality. Also, it is also due to business competition to gain a market advantage (Rentnosari \& Ramana, 2019). Improving the quality and production of salacca zalacca can be done by providing superior seeds, organic fertilizer which is known to improve the quality of salacca zalacca fruit, then training farmers to produce superior seeds and providing organic fertilizer independently so as not to depend on the government. Also, the empowerment of zalacca farmers in processing zalacca plants before harvesting is also important. So that the salacca zalacca produced following expectations if properly treated. This program can later be run in the first and second years.

2) Establishment of Research Institute

To improve quality and yields, farmers need superior seeds from zalacca plants. As is known so far, farmers generally buy zalacca seeds imported from outside the area. So farmers do not have enough knowledge in creating superior seeds. Whereas in local economic development activities, product forward and backward linkage is a strategy that will help improve competitiveness in the market (Humairoh \& Usman, 2016). Therefore we need a research institute that functions to assist farmers in researching to improve the quality of zalacca seeds, to improve the quality and production of zalacca plants themselves. Then this research institute will also help in increasing the innovation of salacca zalacca derivative products. In addition to the large number of products produced, product quality following the standards set in Indonesia is one of the competitiveness strategies. On the other hand, consumers will be more interested if a product has special advantages that other similar products do not have. Here the research institute functions to assist businesses in creating derivative products that have competitiveness while providing added value. The establishment of a research institution begins with the employee's open recruitment (Sonobe, Hu, \& Otsuka, 2004), then make a selection of prospective employees takes 2 weeks. The $3 \mathrm{rd}$ and 4 th months are tested on research institutes. It is hoped that the first to fourth years of research will carry out their functions.

3) Salacca zalacca Commodity Cluster Formation

The establishment of business units and capital is a key element in pioneering and growing clusters 
(Nurhikakia, Kadir, Mahlia, Jusni \& Aditya, 2019). The form chosen by the salacca zalacca commodity producer community in Pronojiwo Subdistrict to grow the cluster is the salacca raw material processing industry into processed products. Cluster is a concentration of economic activities that involve business from upstream to downstream making it possible to do a business combinations. With the growth of clusters, the goverment can work with financial institutions and industry to steer the community towards a wider business world with a promising future.

4) Increasing Salacca zalacca Derivative Product Innovation. Weaknesses of zalacca farmers on zalacca commodities are that farmers have not been able to process zalacca commodities into derivative products so that zalacca farmers do not get maximum benefit.

5) Strengthening Sales Promotions. The competitiveness of zalacca commodities makes it easy for farmers to occupy the market, and open investment opportunities for zalacca-derived products. If the salacca zalacca commodity has gained a place in the market, it does not rule out the possibility of its derivatives.

6) Strengthening the Capacity of Supporting Institutions. Supporting local economic development institutions such as cooperatives, extension agencies, and credit institutions have carried out their respective functions. The cooperative is expected to accommodate the salacca zalacca commodity production and then help access price and market information. Then extension institutions can assist farmers in accommodating aspirations and assist in empowering zalacca farmers. Credit institutions and banks can provide facilities for farmers and business operators in accessing capital and financing. Preparations needed to manage institutions supporting local economic development (Humairoh \& Usman, 2016).

7) The development of science and technology in the agricultural sector from pre-harvest to post-harvest is very beneficial in increasing the effectiveness and efficiency of local economic development activities. Advances in technology in agriculture are expected to help in increasing the production and quality of salacca zalacca and derived products. Salacca zalacca commodity competitiveness began to develop in its derivative products (Satybaldin, Nurlanova, \& Kireyeva, 2016). The added value produced by salacca zalacca derivative products is many times that of the salacca zalacca raw material itself. Instilling the habit of using technology in zalacca farming is expected to be implemented in the first and second years, the third year the community has independently used technology that has developed.

8) Building a partnership forum with other local governments Inter-regional competition in increasing competitiveness to attract investment, occupy markets and have a professional workforce turned out to be able to trigger the emergence of conflicts between regions that led to regional ego problems. Efforts to create conducive market conditions often fail due to regional ego problems. The market knows no administrative boundaries, as well as the chain of local economic development activities (Cho \& Mukoyama, 2018). The problem of a prolonged regional ego will eventually become an obstacle to the growth of the region which causes losses to the region itself due to the breaking of the chain between suppliers and buyers. By building forums and partnerships with other local governments that have similar commodities, it is expected to be able to suppress regional ego. Also, the government can cooperate with each other in stabilizing market prices and provide information about each other on prices and marketing networks, to create a mutually beneficial link between regions.

\section{Conclusion}

\subsection{Summary of Results and Implications}

The results of the study show that salacca zalacca commodity has a comparative advantage and has the potential to become an economic base in Lumajang Regency. The integrated zalacca processing industry that produces a variety of zalacca processed products can provide economic value that increases the final value of each bark. Also, the process of processing salacca zalacca derivative products is also able to produce added value, provide profit margins for workers and employers, as well as contribute to other inputs on each kilogram of product produced. Zalacca processed products have the potential to provide high price margins to farmers and producers if the marketing system is more efficient. Based on the analysis, the salacca zalacca industry cluster is feasible to be developed in Lumajang Regency. recommended strategies for local economic development strategies in regional leading commodities are:

1) Increasing the quality and production of salacca zalacca

2) Establishment of Research Institute

3) Formation of Commodity Clusters 
4) Increasing Product Commodity Derivative Products

5) Strengthening Sales Promotions

6) Strengthening the Capacity of Supporting Institutions

7) Technology Development The development of science and technology in the agricultural sector

8) Establish a partnership forum with local governments

\subsection{Limitations and Future Studies}

As for efforts to increase product competitiveness through policies, it can be done by providing training and mentoring of experts as well as providing subsidies for $\mathrm{R} \& \mathrm{D}$ of trade businesses, to increase the productivity of product trading businesses. Another effort is to increase synergy and the active role of the community and business world to increase productivity, competitiveness, and independence of trade products in a systematic, sustainable, and integrated manner. Increasing the performance of the trade sector and the creative economy can be done through promotion facilities and the creation of appropriate trade policies.

\section{References}

Ayandibu, A. O., \& Houghton, J. (2017). The role of Small and Medium Scale Enterprise in local economic development ( LED ). Journal of Business and Retail Management Research, 11(2), 133-139.

Brusca, I., \& Montesinos, V. (2016). Implementing Performance Reporting in Local Government: A Cross-Countries Comparison. Public Performance \& Management Review, 39(March), 506-534. https://doi.org/10.1080/15309576.2015.1137768

Cahyono, A. E., Kurniawan, M. U., Sukidin, \& Kantun, S. (2018). Community Empowerment Models of Tourism Village Based on Superior Commodities : Realizing Economic Resilience. Journal of Distribution Science, 16(11), 29-36. https://doi.org/10.15722/jds.16.11.201811.29

Cho, M., \& Mukoyama, M. (2018). The Process Model of Retail Format Creation in the Japanese Eyeglasses Industry: The Case Study of JINS Inc. Journal of Distribution Science, 16(2), 5-18. https://doi.org/10.15722/jds.16.2.201802.5

Duncan, C. R. (2007). Mixed Outcomes : The Impact of Regional Autonomy and Decentralization on Indigenous Ethnic Minorities in Indonesia. Development and Change, 38(4), 711-733. https://doi.org/10.1111/j.1467-7660.2007.00430.x

Feldman, M. P., L, L. Á., \& R, Á. O. Á. (2014). The character of innovative places : entrepreneurial strategy , economic development, and prosperity. Small Business Economics, 43(1), 9-20. https://doi.org/10.1007/s11187-014-9574-4

Foley, P. (1992). Local Economic Policy and Job Creation : A Review of Evaluation Studies. Urban Studies, 29(3), 557-598. https://doi.org/10.1080/00420989220080571

Gunawan, C. A. E., \& Santoso, A. (2018). Local Superior Commodities, Regional Specializations and Regional Economic Contributions. Journal of Distribution Science, 16(9), 35-41. https://doi.org/10.15722/jds.16.9.201809.35

Humairoh, S., \& Usman, H. (2016). Competition of Islamic Bank in Indonesia. Journal of Distribution Science, 14(6), 39-44. https://doi.org/10.15722/jds.14.6.201606.39

Koji, Y., \& Bae, I. (2015). Overseas Expansion Support to Small and Medium Enterprises: The Case of Japan and Germany. Journal of Distribution Science, 13(7), 53-61. https://doi.org/10.15722/jds.13.7.201507.53

Kurniawan, M. U., Cahyono, A. E., Sukidin, \& Kantun, S. (2019). Optimization of superior banana product diversification : empowerment of poor communities Optimization of superior banana product diversification : empowerment of poor communities. In IOP Conference Series: Earth and Environmental Science PAPER. IOP Publishing Ltd. https://doi.org/10.1088/1755-1315/243/1/012089

Lee, J. (2016). Analysis of Competitiveness in Steel Distribution Industry between China and Japan. Journal of Distribution Science, 14(3), 31-38. https://doi.org/10.15722/jds.14.3.201603.31

Liao, S. (2014). Fuzzy and Multi Criteria Decisions for Business Management in Product Design Industries. International Journal of Industrial Distribution \& Business, 5(3), 5-14. https://doi.org/10.13106/jidb.2014.vol5.no3.5.

Lund, C., \& Rachman, N. F. (2017). Indirect Recognition. Frontiers and Territorialization around Mount 
Halimun-Salacca zalacca National Park, Indonesia. World Development, $x x$. https://doi.org/10.1016/j.worlddev.2017.04.003

Malysheva, T. V., Shinkevich, A. I., Kharisova, G. M., \& Nuretdinova, Y. V. (2016). The Sustainable Development of Competitive Enterprises through the Implementation of Innovative Development Strategy. International Journal of Economics and Financial Issues, 6(1), 185-191.

Maqin, R. A., \& Sidharta, I. (2017). The Relationship of Economic Growth with Human Development and Electr i c i ty Consumpt $\mathrm{i}$ on in Indonesia. International Journal of Energy Economics and Policy, 7(3), 201-207.

Muda, I., Siregar, H., Sembiring, S., Ramli, Manurung, H., \& Zein, Z. (2018). Economic Value of Palm Plantation in North Sumatera and Contribution to Product Domestic Regional Bruto Economic Value of Palm Plantation in North Sumatera and Contribution to Product Domestic Regional Bruto. In IOP Conference Series: Materials Science and Engineering PAPER (pp. 1-6). https://doi.org/10.1088/1757-899X/288/1/012080

Nauta, P. Di, Merola, B., Caputo, F., \& Evangelista, F. (2015). Reflections on the Role of University to Face the Challenges of Knowledge Society for the Local Economic Development. Journal of the Knowledge Economy, 9(1), 180-198. https://doi.org/10.1007/s13132-015-0333-9

Nugroho, I., Pramukanto, F. H., \& Negara, P. D. (2016). Promoting the Rural Development through the Ecotourism Activities in Indonesia. American Journal of Tourism Management, 5(1), 9-18. https://doi.org/10.5923/j.tourism.20160501.02

Nurhikakia, K. A. R., Mahlia, M., Jusni, \& Aditya, H. P. K. P. (2019). Determinant of Market Orientation on SME Performance: RBV and SCP Perspective. Journal of Distribution Science, 17(9), 35-45. https://doi.org/10.15722/jds.17.9.201909.35

Park, C. J., \& Jeong, T. (2012). Study on the Measurement of Management Performance based on BSC: Examining Japanese Food Manufacturers. Journal of Distribution Science, 10(11), 11-20. https://doi.org/10.15722/jds.10.11.201211.11

Pathak, S., \& Muralidharan, E. (2016). Informal Institutions and Their Comparative Influences on Social and Commercial Entrepreneurship: The Role of In-Group Collectivism and Interpersonal Trust. Journal of Small Business Management, 54, 168-188. https://doi.org/10.1111/jsbm.12289

Pike, A., Marlow, D., Mccarthy, A., \& Brien, O. (2015). Local institutions and local economic development: The Local Enterprise Partnerships in England, 2010. Cambridge Journal of Regions, Economy and Society, 8(2), 185-204. https://doi.org/10.1093/cjres/rsu030

Raco, M. (2000). Assessing community participation in local economic development - lessons for the new urban policy. Political Geography, 19(1), 573-599. https://doi.org/10.1016/S0962-6298(00)00004-4

Rentnosari, L., \& Ramana, F. (2019). Mitigating Economy Risk in The Digital Era Through Export Diversification. International Journal of Industrial Distribution \& Business, 10(9), 19-24. https://doi.org/10.13106/ijidb.2019.vol10.no9.19.

Roh, B., Kim, H., Yoo, C., \& Kim, G. (2015). Counteractions against Changes of Logistics Environment in Northeast Asia. Journal of Distribution Science, 13(5), 23-31. https://doi.org/10.15722/jds.13.5.201505.23

Ryu, J. S. (2019). Is Consumer Characteristics and Shopping for Fashion in the Omni-channel Retail Environment. Journal of Business, Economics and Environmental Studies, 9(4), 15-22. https://doi.org/10.13106/jbees.2019.vol9.no4.15

Satybaldin, A. A., Nurlanova, N. K., \& Kireyeva, A. A. (2016). A Ne ew Policy of Spatia al Development of Kazakhsstan on the Principles of Inclussiveness and Smart Specialiization. Journal of Asian Finance, Economics and Businessand Business, 3(3), 93-102. https://doi.org/10.13106/jafeb.2016.vol 3.no3.93

Seo, D., \& Coo, B. (2017). The Global Distribution Direction of Defense Industry in Eastern Europe under the New Cooperation Strengthened. Journal of Distribution Science, 15(1), 83-93. https://doi.org/10.15722/jds.15.1.201701.83

Shi, L., Chu, E., Anguelovski, I., Aylett, A., Debats, J., Schenk, T., ... Roberts, J. T. (2016). adaptation research. Nature Publishing Group, 6(2), 131-137. https://doi.org/10.1038/nclimate2841

Sonobe, T., Hu, D., \& Otsuka, K. (2004). From inferior to superior products: An inquiry into the Wenzhou model of industrial development in China. Journal of Comparative Economics, 32(3), 542-563. https://doi.org/10.1016/j.jce.2004.05.001 
Sovacool, B. K., Walter, Gg., Andrews, N., \& Graaf, T. Van De. (2016). Energy Governance, Transnational Rules , and the Resource Curse : Exploring the Effectiveness of the Extractive Industries Transparency Initiative ( EITI ). World Development (2016), xx, 1-14. https://doi.org/10.1016/j.worlddev.2016.01.021

Sukewijaya, I. M., Rai, I. N., \& Mahendra, M. S. (2009). Asian Journal of Food and Agro-Industry. Asian Journal of Food and Agro-Industry, (Special Issue), 37-43.

\section{Copyrights}

Copyright for this article is retained by the author(s), with first publication rights granted to the journal.

This is an open-access article distributed under the terms and conditions of the Creative Commons Attribution license (http://creativecommons.org/licenses/by/4.0/). 